$$
\begin{aligned}
& \text { CONOA- } \\
& \text { CONF- } 960845-2
\end{aligned}
$$

\title{
VISCOSITY OF CONCENTRATED SUSPENSIONS OF SPHERE/ROD MIXTURES
}

\author{
R. Mor ${ }^{1}$, M. Gotdieb ${ }^{1 *}$, A.L. Graham², and L.A. Mondy ${ }^{3}$ \\ ${ }^{1}$ Deparment of Chemical Engineering, Ben Gurion University, Beer Sheva, 84105 ISRAEL \\ ${ }^{2}$ Los Alamos National Laboratory, Los Alamos, New Mexico 87545 USA \\ ${ }^{3}$ Sandia National Laboratorics. Albuqucrquc. New Mcsico 87185-0834 USA \\ * To whom comespondence should be addressed
}

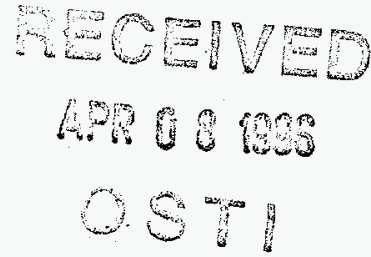

\section{INTRODUCTION}

Most investigations on the rheology of concentrated suspensions have focused on monodisperse suspensions of cither spherical or rodlike particles. In practice, suspensions contain paricles that are polydisperse both in size and in slape. Only a limited number of studies lave been devoted to the problem of size polydispersity and even less is known about the behavior of suspensions composed of particles of different shapcs. In this papcr wc provide cxpcrimental data for the low shcar rate viscosity of concentrated suspensions of neutrally buoyant, rod-sphere mixtures and develop a simple plenomenological model for the viscosity of such systems.

Farris [1] devcloped a model for the viscosity of multimodal suspensions of spheres. In his model, for each fraction of a given particle size, the smaller particles in the suspension do not interact with the larger particles and are 'sensed' by the large particles as part of a continuous Newtonian suspending fluid. In what follows, we use Farris's concepts to devclop an cquation for the viscosity of a suspension of a mixture of rodlike and spherical particles. If the rods are large enough relative to the spheres, we may consider the spherical particles as part of the homogeneous suspending continum. Let us define an apparent sphere volume fraction $\phi_{s}^{*}=V_{s} /\left(V_{0}+V_{s}\right)=\phi_{s} /\left(1-\phi_{s}\right)$ where $V$ is volume, $\phi$ is the volume fraction. and the subscripts 0 . I. s. T stand for the fluid, rods, spheres, and total solids respectively. If we assume the viscosity of a suspension composed of spheres and rods is the same as the viscosity of a suspension of rods suspended in a Newtonian homogeneous fluid of viscosity identical to the viscosity of

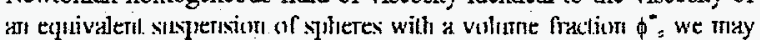
write:

$$
\begin{aligned}
& \mu_{\text {ruspension }}\left(\phi_{T}\right)=\mu_{\text {reltrods }}\left(\phi_{t}\right) \mu_{\text {spheres }}\left(\phi^{*}\right) \\
& \mu_{\text {spheres }}\left(\phi_{s}^{*}\right)=\mu_{\text {relisphecres }}\left(\phi_{s}^{*}\right) \mu_{0} \\
& \mu_{\text {rel }}\left(\phi_{T}\right)=\mu_{\text {rel spheres }}\left(\phi_{s}^{-}\right) \mu_{\text {relroos }}\left(\phi_{s}\right)
\end{aligned}
$$

IIcre wc adopt the Thomas rclations for sphcres [2] and Millikcn's for randomiy oriented rods with aspect ratio of 20 [3]. The relative viscosity of a mixed suspension may now be calculated for any combination of rods (of aspect ratio 20) and spheres.

\section{EXPERIMENT $\Lambda \mathrm{L}$}

The experimental apparatus. materials. and methods have been described in great detail elsewhere [3-5]. Suspensions composed of mixtures of poly(methyl methacrylate) spheres with diameter of $3.175 \mathrm{~mm}$ and rods with length of $31.65 \mathrm{~mm}$ and diamcter of $1.587 \mathrm{~mm}$ wcre uscd. The rodsphere mixtures were suspended in a three-main-components Newtonian fluid with $50 \%$ wt alkylaryl polyether alcohol $35 \%$ wt polyalkylene glycol. and $15 \%$ wt tetrabromoethane. The quantity of tetrabromoethane in the mixiture was adjusted so thal the dertsily dotd the refraclive ividex of the fluid would match those of the PMMA particles. The falling balls with diameters between $6.35 \mathrm{~mm}$ and $15.88 \mathrm{~mm}$ were either chrome-plared steel ball bearings. monel or tungsten carbide. The trajectories of the talling balls were recorded on a high-speed digitizing video system. $\Lambda \mathrm{n}$ average velocity was determined by measuring the elapsed time for the ball to scttle a known distance on the screcn. Up to 40 individual drops were required for each dara point.

\section{RESULTS AND DISCUSSION}

The rclative viscosity is obtained from the dimcnsionless ratio of the measured Stokes viscosity of the suspension, incorporating the Faxen boundary correction [3-5]. to the viscosity of the suspending fluid. The average relative viscosity for each suspension is obtained by averaging up to 120 separate ball drops for any given suspension. In Fig. 1 the mcasurcd avcragc viscositics (sombols) arc comparcd to the theory described in the first section (lines). The agreement between the limited number of available experimental points and the calculated lines is very good. This agreement seems to validate the assumption that, in a suspension in which two populations of solid particles with large size differcnec cocsist, the larger particles 'scnsc' the smaller particles only as part of an effective suspending continuum

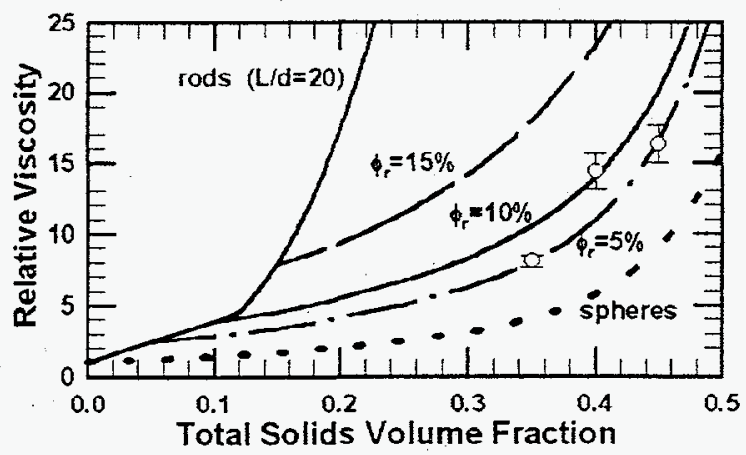

Fig 1. 'The relative viscosity of the mixed suspension as function of the

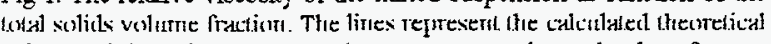
values and the points represent the average experimental values for any given composition.

\section{REFERENCES}

1. R.J. Fanis, Trans. Soc. Rheol., 12, 281(1968).

2. D.G.Thomas, J. Colloid Sci., 20, 267 (1965).

3. W.J. Milliken L.A. Mondy. M. Gottlieb, A.L. Graham and R.L. Powell, J. Hluid Mech., 202, 217 (1989).

4. W.I. Millikem, T..A. Moucly, M. Gowhit), A.I. Grubart, ant R.T. Powell Phys. Chem. Hydro., 11, 341 (1989).

5. R. Mor, M. Gottlieb, A.L. Graham, L.A. Mondy, Chem. Eng. Comm. in press (1996). 


\section{DISCLAIMER}

Portions of this document may be illegible in electronic image products. Images are produced from the best available original document. 


\section{DISCLAIMER}

This report was prepared as an account of work sponsored by an agency of the United States Government. Neither the United States Government nor any agency thereof, nor any of their employees, makes any warranty, express or implied, or assumes any legal liability or responsibility for the accuracy, completeness, or usefulness of any information, apparatus, product, or process disclosed, or represents that its use would not infringe privately owned rights. Reference herein to any specific commercial product, process, or service by trade name, trademark, manufacturer, or otherwise does not necessarily constitute or imply its endorsement, recommendation, or favoring by the United States Government or any agency thereof. The views and opinions of authors expressed herein do not necessarily state or reflect those of the United States Government or any agency thereof. 